\title{
CONSTRUCTION AND EVALUATION OF PROTOTYPE SCREW PELLETING MACHINE FOR SUGAR BEET TOPS
}

\section{ABOU-SHIESHAA. R* R. KHOLIEF* H. EL-KHATEEB*}

\section{ABSTRACT}

The objective of the present study is to construct and evaluate a prototype screw pelleting machine to be used for sugar beet tops. Pelleting machine was fabricated on a private workshop in Dosuq City and tested at Sakha Animal Production Research Station Kafr El-Sheikh Governorate during summer season of 2010. The effect of screw revolving speeds, raw material moisture content and die hole diameters on machine productivity, power requirement, energy consumed and pelleting cost. Also, the effect of tested parameters on pellets quality such as stiffness, durability and pellets bulk density were taken into consideration. Hence the pellets were subjected to heated air at $70 \mathrm{oC}$, during their treatment in the drying unit.

Results indicated that, the optimum operating conditions of the proposed prototype was at screw revolving speed of $180 \mathrm{rpm}$, raw materials moisture content of $25.74 \%(w . b)$ and die hole diameter of $16 \mathrm{~mm}$. Whereas, it gave machine productivity of $0.098 \mathrm{Mg} / \mathrm{h}$, power requirement of $3.10 \mathrm{~kW}$ and energy consumed of about $31.71 \mathrm{~kW} . \mathrm{h} / \mathrm{Mg}$. Moreover, the optimum operating conditions gave the best pellets quality as well as pellets stiffness of $135.5 \mathrm{~N}$, durability of $95.43 \%$ and pellets bulk density of about $2.136 \mathrm{~g} / \mathrm{cm}^{3}$. However, the cost calculations proved that, the pelleting cost by using the proposed prototype was reached about 105.20 EGP/Mg.

\section{INTRODUCTION}

ugar beet is an important crop, not only for sugar production, but also for producing fodder and organic matter for the soil. The cultivated area of sugar beet were 104,525 hectare gave 5,138,190 of sugar beet roots and 1,493,226 tons tops, respectively (ASMOA, 2009). Beet tops consist of about one third crown and two thirds leaves.

\footnotetext{
* Senior researcher in Agric. Eng. Res. Inst., A.R.C., Dokki - Giza.
} 
The green mass of tops ranges from 75 to $80 \%$ of the mass of topped beets.

Feeding shortage is one of the most serious problems facing the animal breeders. However, it can be solved by selecting the proper fodder diet in the acceptable phase. During the period from June to October, most of the Egyptian farmers feed their livestock on very poor quality roughage such as rice and wheat straw. The necessity to dry fodder feed for farm animals in summer period has been increased vigorously in Egypt. Due to lack of fodder crops and concentrates for feeding farm animals, several efforts have been done to improve the nutritive value of crops by-product for feed animals. Sugar beet is one of these crops which, gives large quantities of green tops as a by-product after harvesting the crop.

On the other hand the riddance from crop residues is a great environmental problem because of great quantities from agricultural residues such as rice straw, maize stalks, cotton stalks and sugar beet tops. Burn has had effects on health for population and played a great role in agricultural residues value wasting. This by-products has some disadvantages for using beet tops in feeding animals because of its ferment quickly causing flying breeding nuisance and always present potential air, plant diseases and water pollution problems.

Beet tops are fed mostly to cattle and sheep either ensiled, fresh or pellets from as cured in small in the field. Beet tops are palatable and nutritious for animals. Ruminants are able to utilize large quantities without injury. Beet tops contain about two-thirds of the digestible nutrients found in corn silage (Martin et al 1976). So, drying and pelleting sugar beet tops is one of the important method for solving some of the problems of animal feeding and minimize such problems of disposal and pollution. It may offer a significant reduction in feed cost and minimize the requirement of expensive feed stuff.

The advantages of pelleting could be summarized as follows by Dobie (1959, and 1961) : a) better keeping quality, b) good bulk handling characteristics, c) more palatability for animals, d) reducing storage space, e) minimum waste, f) optimum feeding results, g) homogeneity from the time of production up to offering to the animal,

h) pelleting 
for ruminants decreases the ratio of acetate to propionate in the rumen and i) reducing handling costs.

Susawa (1978) showed that, the reciprocating machine operates on the same principle as most balers, except that the plunger and compression chamber are so designed as to provide the increased pressure necessary to produce a wafer. The material supplied in front of it into a cylinder. By selecting an adequate length of the cylinder, and the degree and direction of taper of inner surface, the material is pressed in the cylinder and comes out as a wafered product. The machine of this type alone, being not combined with the dryer, is also used for wafering rice straw. He also added that, the factors affecting on compression (wafer ability) in the following points: a) moisture content of materials, b) cut length materials, c) kind of materials, d) temperature of materials, and e) compression pressure of plunger and wafer density. Whereas short cutting causes an increased flow of product, but cut length of 2 to $3 \mathrm{~cm}$ is adequate from the viewpoint of performance of machines and feeding animals.

Ramadan (1980) mentioned that, the developed design (roller- type) of pelleting machine was used to produce pellets with different mixtures of berseem and molasses mixed by calcium oxide. The most efficient percentage of the mixture was two parts of molasses to one part of calcium oxide in mass. Also, the optimum range of moisture content for the final material under pressure was ranged from 12 to $15 \%$.

Abd-El-Rahim et al. (1981) reported that energy requirements for compression cotton stalks increased with increasing applied pressure and with decreasing moisture content of stalks.

Approximately $2.0 \mathrm{~kW} . \mathrm{h} /$ ton is required to produce a cotton stalk wafer of $15 \%$ moisture content for a ratio: $\frac{L}{D}=0.6$

Where:

$\mathrm{L}=$ Length of stalk, $\mathrm{mm}$ and $\quad \mathrm{D}=$ Die diameter, $\mathrm{mm}$.

Ismael (2001) developed and tested a pelleting machine (screw type) to produce pellets for poultry from some processing residue (haricot, okra, 
and pea wastes) with other components. He showed that the energy consumed in mixing, compressing and cutting of ration containing haricot, okra and pea wastes were $38.11,28.94$ and $24.25 \mathrm{~kW} . \mathrm{h} / \mathrm{ton}$, respectively at pellet diameter $5 \mathrm{~mm}$ for the best physical proportion of the pellets.

Fasina and Sokhansanj (1992) pointed out that the moisture increase in alfalfa cubes and pellets is exponential to a point of disintegration. The durability of cubes and pellets increased initially with increasing in moisture content up to $4 \%$ point of moisture increase and then decrease with further increase in their moisture levels.

Kholief (1996) found that sugar beet tops pellets can be stored without any injury below the moisture of about $18 \%$ and its palatability for buffaloes was tasted good and they ate pellets readily without leaving residues.

Khalil (2001) compared three different types of complete pelleted rations, whereas the control ration (A) contained $50 \%$ berseem hay, ration (B) contained $25 \%$ berseem hay and $25 \%$ dried sugar beet tops (DSBT) and ration (C) contained 50\% (DSBT). Berseem hay and (DSBT) were grounded by mill grinding after that mixed with other concentrates ingredients and manufactured as the complete pelleted in pelleting machine. He also added that, the density of pellets were 1.392, 1.841 and $2.359 \mathrm{~g} / \mathrm{cm}^{3}$ and its hardness were about 13.62, 15.43 and $18.97 \mathrm{~kg}$, while its mass loss were $9.73,4.13$ and $2.56 \%$ for complete pelleted rations A, B and C, respectively. Generally increasing the level of DSBT in the complete pelleted rations increased the density and hardness of pellets and decreased its mass loss.

According to the Egyptian standard specification for prepared animal feeds and feedstuffs (EOS, 1987), compressed feeds are sized into four categories as follows: a) sizes $<2 \mathrm{~mm}$ in diameter ranked: powder or mash, which was used for all types of poultry and birds. b) sizes $2-5 \mathrm{~mm}$ in diameter, which was used for rabbits, goats and fishes. c) sizes 5$10 \mathrm{~mm}$ in diameter for small animals ( $<6$ months). and d) sizes $10-22 \mathrm{~mm}$ in diameter for large animals ( $>6$ months). 
Gupta (2001) reported that, the feed pelleting machine can be operate by $5 \mathrm{hp}$ electric motor used for making feed pellets of forage crops, with or without concentrate at a capacity of 60 to $80 \mathrm{~kg} / \mathrm{h}$. The diameter of feed pellets can be varied from $5 \mathrm{~mm}$ to $40 \mathrm{~mm}$ with length of 2.5 to $12 \mathrm{~cm}$.

The objective of the present study is to construct and evaluate a prototype screw pelleting machine for sugar beet tops.

\section{MATERIALS AND METHODS}

\section{Materials:}

The present study was carried out to construct screw pelleting machine. It was fabricated at private workshop in Dosuq city and experiments were carried out at Sakha Animal Production Research Station Kafr El-Sheikh Governorate during summer season of 2010. The machine consists of two main parts (screw pelleting and drying units) joined together on the main frame by means of ball bearing and fixed by bolts as shown in Fig. 1. The specifications of pelleting machine are indicated in Table 1.

\section{a) Frame:}

The frame was reinforced with four corners. It was manufactured from angle bars $5 \times 5 \times 0.5 \mathrm{~cm}$. The frame includes elements to fix hitching systems, screw pelleting unit drying unit and two electrical motors.

\section{b) Screw pelleting unit:}

The screw pelleting unit consists of compressing screw, housing provide with hopper. The compressing screw has dimensions of $45 \mathrm{~cm}$ long, $20.75 \mathrm{~cm}$ diameter, and pitch of $8.5 \mathrm{~cm}$. Hence the screw was tapered from the back to the die and it was made of cast iron. The die is very important part for forming pellets with the desired diameter as shown in Fig. 2. So, it was used for blocking the housing from the end. It was made from hard steel with dimensions of $23 \mathrm{~cm}$ diameter and $3 \mathrm{~cm}$ thick. It has 12 holes with 8,12 , and $16 \mathrm{~mm}$ diameter with a wider conical shape from the entry side. 


\begin{tabular}{|c|l|}
\hline No. & Part name \\
\hline 1 & Collecting box. \\
2 & Ovtlet flow. \\
3 & Main fram. \\
4 & Drying unit. \\
5 & Elctic motor. \\
6 & Pulley. \\
7 & Feed hopper. \\
8 & Control gate. \\
9 & Screw pelleing. \\
10 & Ovtlet die. \\
11 & Flexible plate. \\
12 & Air distribution \\
& chamber. \\
13 & Spring. \\
14 & Air heating unit. \\
15 & Blowe. \\
\hline
\end{tabular}
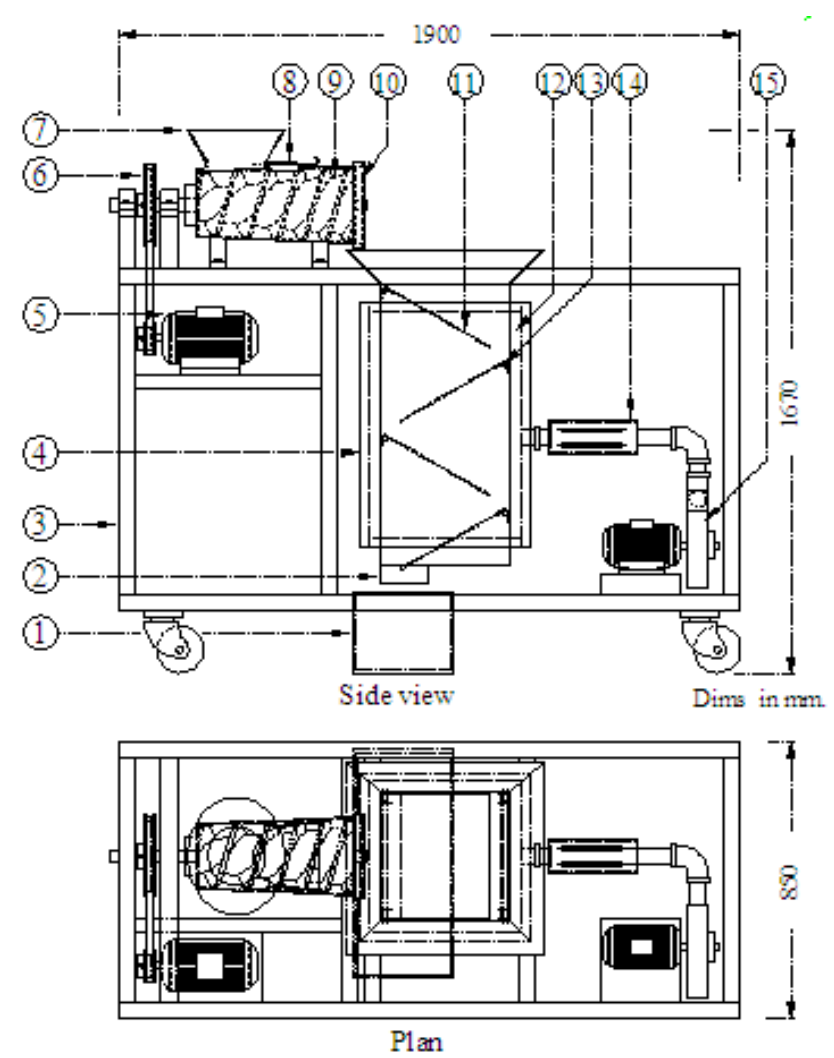

Fig. 1: A schematic digram of the constructed screw pelleting machine

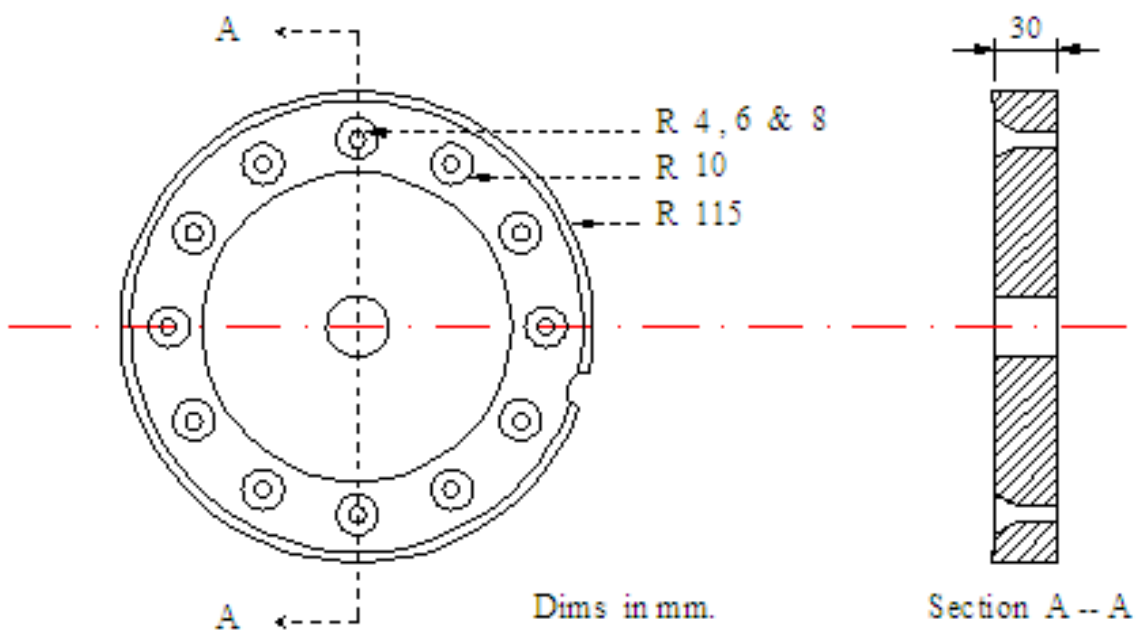

Fig. 2: The outlet die.

Tabıe 1: ıecnnical specirıcatıons or tne screw pelıetıng macnine. 


\begin{tabular}{|c|l|}
\hline \multicolumn{1}{|c|}{ Items } & Specifications \\
\hline Main dimension: & \\
Overall length, cm & 190 \\
Overall width, cm & 85 \\
Overall height, cm & 167 \\
Total machine mass, kg & 240 \\
Screw: Average length, cm & \\
Average diameter, cm & 45 \\
Average pitch (trough width), cm & 20.75 \\
Average peak height (trough depth), cm & 8.5 \\
Flights No. & 3.75 \\
Electric motor, hP ( $\mathrm{kW})$ & 12 \\
Drying unit: & $4(3)$ \\
- Outer length, cm & 52 \\
Outer width, cm & 52 \\
Overall height, cm & 100 \\
No. of flexible plate & 4 \\
Total unit mass, kg & 70 \\
Electric motor, $\mathrm{hP}(\mathrm{kW})$ & $0.53(0.4)$ \\
Hopper: & \\
Average length, cm & 36 \\
Average diameter, cm & 30 \\
\hline
\end{tabular}

\section{c) Drying unit:}

The moisture contents of pellets seems to be higher for packing or handling so, pellets should be dried. After compressing, the pellets was directly passed through the drying unit. It consists mainly from silo with dimensions of $100 \times 52 \times 52 \mathrm{~cm}$ and it was made from metal sheet $3 \mathrm{~mm}$ thick. However, the silo was isolated by wood and it was provided with four flexible plates hinged by tension spring fixed with rotating axes to delay the dropping of pellets and to subject them to the blowed heated air. Hence the blowed air was heated by the assistment of electric heater to obtain the desired temperature. The air flow was forced through the holes distributed all over the silo wall to ensure its effect on the pellets during their passing from the pelleting units into the flexible plates to be collected outside the drying unit on collecting box with dimensions of 70 $\mathrm{x} 30 \times 25 \mathrm{~cm}$. 


\section{d) Power transmission system:}

Two different size of electric motors were used to operate both the pelleting and the blower in the drying units. The main one has power of $3.0 \mathrm{~kW}$ and an auxiliary motor with $0.4 \mathrm{~kW}$. The main motor drives the screw pelleting unit by using different sizes of pulley and " $\mathrm{V}$ " belt. However, the auxiliary motor drives the blower in the drying unit.

\section{Experimental procedures:}

The proposed prototype was used for pelleting grinding sugar beet tops mixed with other ingredients. Beet tops were collected after harvesting and spread on the ground. They were turned up side down every other day at 9 a.m. after complete drying, sugar beet tops were collected and then grinded by using roller mill grinding machine. Then it was mixed by hand with other concentrates ingredients and manufactured as the complete pelleted rations as shown in Table 2 .

The chemical composition of dried sugar beet tops on dry matter basis were $77.62 \%$ for dry matter $(12.77 \%$ for crude protein, $14.44 \%$ for crude fiber, $2.22 \%$ for either extract and $48.19 \%$ for nitrogen free extract) and $22.28 \%$ for ach, respectively. It can be noticed that, the crude protein and fiber were lowest, but the nitrogen free extract and ash content were highest (Khalil, 2001).

Tests were carried out by using four screw revolving speeds: 60, 100, 140 , and $180 \mathrm{rpm}$, three different levels of ration materials moisture content: $25.74,30.62$ and $36.59 \%$ (w.b.) and three die hole diameters of 8,12 and $16 \mathrm{~mm}$. Hence drying temperature was kept constant at $70{ }^{\circ} \mathrm{C}$ during pelleting process.

\section{Table 2: Pellets components of ingredients.}

\begin{tabular}{|l|l|}
\hline Ingredients & Weight basis, \% \\
\hline Dried sugar beet tops & 50.00 \\
Yellow corn & 14.00 \\
Wheat bran & 30.00 \\
Molasses & 3.00 \\
Limestone & 1.50 \\
Common salt & 1.00 \\
Minerals & 0.50 \\
\hline
\end{tabular}




\section{Measurements:}

a) Estimation of power and energy consumption:

Ammeter and Voltmeter were used for measuring current strength and potential difference, respectively before and during experiments. Reading of Ammeter (I) and Voltmeter (V) were taken before and during each treatment. The power consumption $(\mathrm{kW})$ was calculated from the values of Ampere (I) and Volt (V). The power consumption (P) was calculated by using the following formula (Lockwood and Dunstan,1971).

Power requirment $=\frac{\sqrt{31 \cdot V \cdot \cos \theta}}{1000},{ }_{j} \mathrm{~kW}$

\section{Where:}

I = Line current strength in Amperes;

$\mathrm{V}=$ Potential difference (Voltage) being equal to 380 Volts;

$\operatorname{Cos} \Theta=$ Coefficient of utilized power (being equal 0.71 ) and

$\eta \dot{=}=$ Mechanical efficiency of motor assumed $95 \%$.

The energy requirements was calculated by using the following equation:

$$
\text { Energy requirment }=\frac{p}{C}
$$

Where:

$$
\begin{aligned}
& P=\text { Power requirement in, } k W ; \\
& C=\text { Machine productivity in, } \mathrm{Mg} / \mathrm{h} .
\end{aligned}
$$

\section{b) Moisture content determination:}

The desired moisture content of pellets component ingredients was adjusted by drying or rewetting. However the moisture content was determined according to AOAC, (1994). The standard air oven method using $25 \mathrm{gm}$ samples placed in air oven at $130 \mathrm{C}^{0}$ for 16 hours.

c) determination of pellets stiffness:

A portable stiffness tester (174866) Kiyo Seisakusho, L.T.D. was used to determine the rupture force in Newton. 


\section{d) Durability test:}

Durability of pellets is determined by subjecting them to treatments similar to those which the might experience in normal farm handling operations. The ASAE-S269.3 device was used for testing purpose under $50 \mathrm{rpm}$ for one minute and the durability index was calculated by using the following equation:

Durability index $=\frac{M a}{M b} \times 100, \%$

Where:

$\mathrm{Ma}=$ Mass of pellets after shaking, $\mathrm{g}$ and

$\mathrm{Mb}=$ Mass of tested pellets before shaking, $\mathrm{g}$.

\section{e) Pellets bulk density:}

It was calculated by using the following equation:

Density after formint $=\frac{M_{d}}{V d},\left(\mathrm{~g} / \mathrm{cm}^{3}\right)$

Where:

$\mathrm{Md}=$ Pellets sample mass, $\mathrm{g}$ and

$\mathrm{Vd}=$ Pellets sample volume, $\mathrm{cm}^{3}$.

\section{f) Machine operation costs:}

The machine operation costs were calculated according to the following assumption:

\section{Fixed costs:}

- Depreciation $=($ List price - Salvage value $) /$ Machine life, EGP/year Salvage value is $10 \%$ of original cost.

- Interest $=$ Interest rate (List price - Salvage value) $/ 2, \mathrm{EGP} /$ year

- Shelter, taxes insurance $=2 \% \mathrm{x}$ List price.

Total fixed cost $=$

$$
\left\lfloor\frac{\text { Depreciation }+ \text { Shelte, taxes and incurance }}{\text { Hours of use per year }}\right\rfloor, E G P / h
$$




\section{Variable costs:}

- Repairs and maintenance $=5.77 \%$ of List price / Hours of use Per year, EGP / $\mathrm{h}$ as mentioned by (Bowers, 1987)

-Electricity cost =power consumed, (kW.h) x electricity price, EGP /h.

- Greasing $=2.0 \times .025 /$ No. of hours per day, EGP/h

- Labor cost $=4.0 \mathrm{EGP} / \mathrm{h}$

Total Variable costs $=($ Repair and maintenance cost + Electricity +

Greasing + Labor), EGP./h

The cost of production (CP) was calculated by using the following formula:

$\mathrm{CP}=$ Total cost $/$ Machine productivity, EGP/Mg

\section{RESULTS AND DISCUSSION}

\section{a) Machine productivity:}

Figure 3 illustrates the effect of screw revolving speed, die hole diameter and pellets ration moisture contents on machine productivity. It was found that, machine productivity increased by increasing the screw revolving speeds, die hole diameter and pellets ration moisture contents. Data presented in the same Figure showed that the increase of screw revolving speeds from 60 to $180 \mathrm{rpm}$ increases the machine productivity by $23.44,30.77$ and $33.84 \%$ for die diameter of $8 \mathrm{~mm}$ and pellets ration moisture contents of $25.74,30.62$ and $36.59 \%$, respectively.

However, the data also showed that the increase of die hole diameter from 8 to $16 \mathrm{~mm}$ tends to increase the machine productivity by 12.5 , 16.92 and $20.90 \%$ with screw revolving speed of $60 \mathrm{rpm}$ at the same above mentioned pellets ration moisture contents.

Meanwhile, the increase in pellets ration moisture content from 25.74 to $36.59 \%$ leads to increase the machine productivity by $4.69 \%$ with die hole diameter of $8 \mathrm{~mm}$ and screw revolving speed of $60 \mathrm{rpm}$. This increase in machine productivity may be attributed to the decrease in the time required for pelleting process. However, the increase in machine productivity as pellets ration moisture content increase may be due to the increase in flow rate into the extrusion during the 


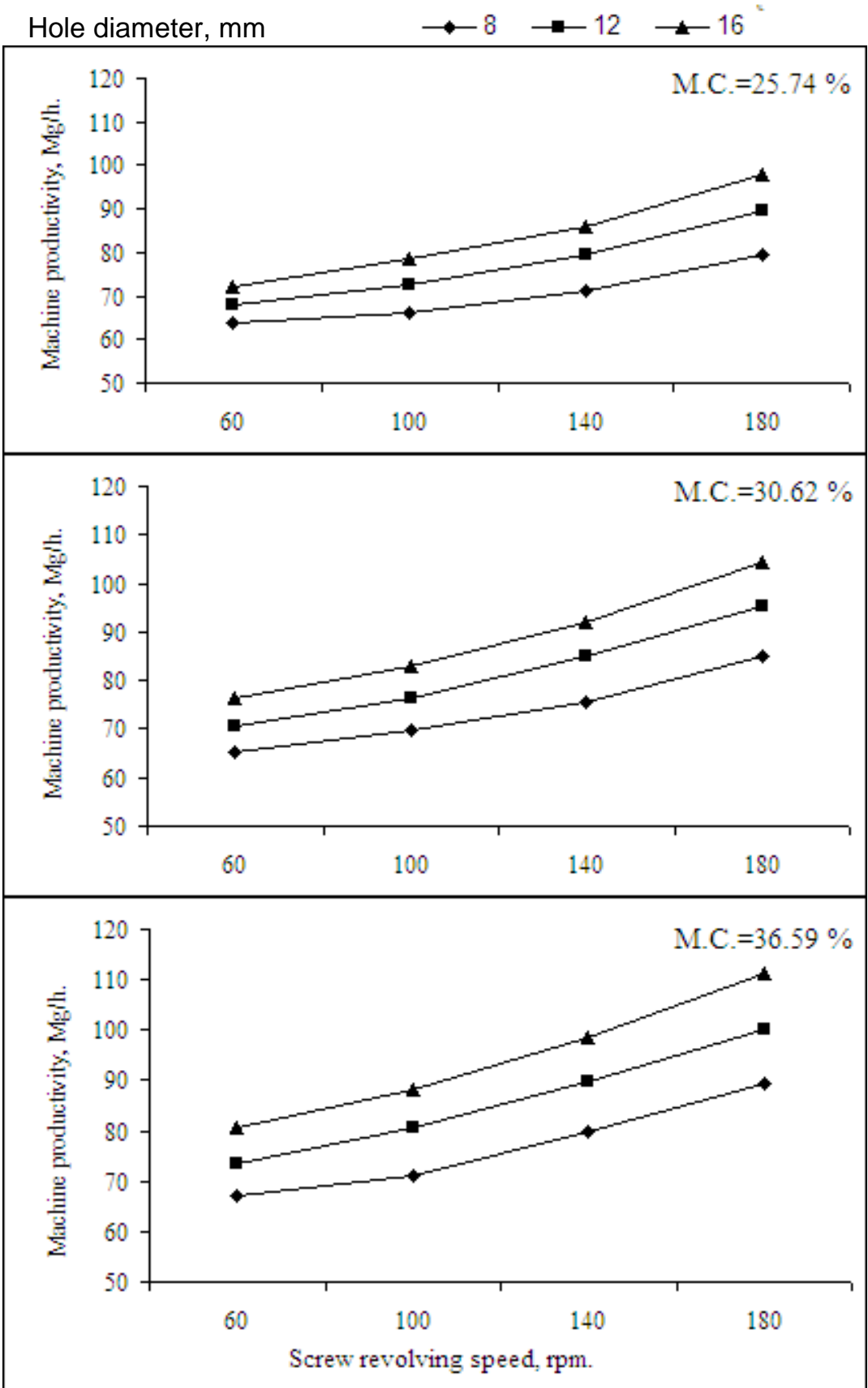

Fig.3: Effect of screw revolving speed, die hole diameter and ration moisture content on machine productivity. 
pelleting process by increasing both die hole diameter and screw revolving speeds.

\section{b) Power and energy consumption:}

Referring to the effect of screw revolving speeds, die hole diameters and pellets ration moisture contents on power and energy consumption as shown in Fig.4. It is conceivable that, the increase of screw revolving speeds from 60 to $180 \mathrm{rpm}$ tends to increase the power requirement from 2.88 to $3.41 \mathrm{~kW}$ with die hole diameter of $8 \mathrm{~mm}$ and pellets ration moisture content of $25.74 \%$. Meanwhile, the same increase in screw revolving speed decreases the energy consumption from 45.18 to 42.93 $\mathrm{kW} . \mathrm{h} / \mathrm{Mg}$ at the same above mentioned conditions. The same results were obtained with other die hole diameters and screw revolving speeds.

From the previous data it is evident that, the increase in die hole diameter from 8 to $16 \mathrm{~mm}$ tends to decrease the power requirement from 2.88 to $2.51 \mathrm{~kW}$ at screw revolving speed of $60 \mathrm{rpm}$ and pellets ration moisture content of $25.74 \%$. However, the same increase in die hole diameter decreases the energy consumption from 45.81 to $34.74 \mathrm{~kW} . \mathrm{h} / \mathrm{Mg}$, at the same above mentioned conditions. The same trend were obtained with the other screw revolving speeds and pellets ration moisture contents.

Moreover, the increase in pellets ration moisture contents from 25.74 to $36.59 \%$ decreases the power requirement by 17.36, 15.46, 14.38 and $14.37 \%$ with die hole diameter of $8 \mathrm{~mm}$ and screw revolving speeds of $60,100,140$ and $180 \mathrm{rpm}$, respectively. The same results were obtained with other die hole diameters. In the same manner, the same increase in pellets ration moisture contents reduce the energy consumed by 21.55 , $21.56,23.41$ and $23.97 \%$ at the same above mentioned conditions.

\section{c) Pellets stiffness:}

Stiffness of pellets were taken into consideration to investigate the effect of mechanical action during pelleting process under different operation conditions. Hence the stiffness of pellets were measured just after drying to find out its ability for breaking-up. Data presented in 
Energy $\quad \cdots+\cdots 6 \cdots \cdots 12 \cdots \cdots 16 \quad$ Power $\rightarrow-8 \rightarrow-12 \rightarrow-16$

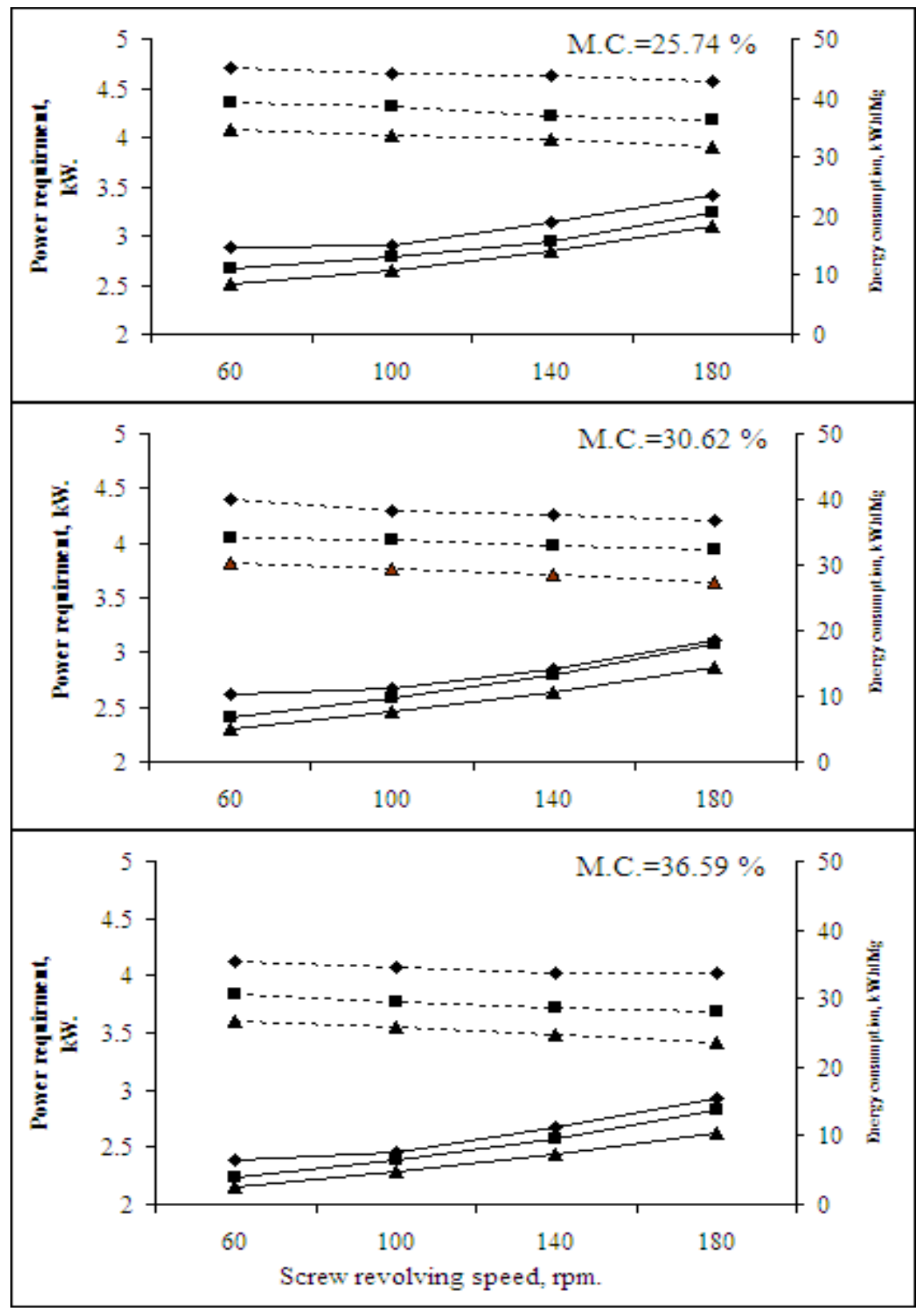

Fig.4: Effect of screw revolving speed, die hole diameter and ration moisture content on power requirement and energy consumption. 
Fig. 5 shows the effect of screw revolving speeds, die hole diameter and pellets ration moisture contents. It can be stated that, the stiffness of pellets were increased by the increase of screw revolving speeds, meanwhile they were decreased by increasing both die hole diameters and pellets ration moisture contents. Whereas, the increase of screw revolving speeds from 60 to $180 \mathrm{rpm}$ leads to increase the pellets hardness by $11.61,12.72$, and $12.45 \%$ with pellets ration moisture content of $25.74 \%$ and die hole diameters of 8,12 , and $16 \mathrm{~mm}$, respectively. However, the same results were obtained with other pellets ration moisture contents .

In the same manner, the increase of die hole diameter from 8 to $16 \mathrm{~mm}$ the pellets stiffness decreased from 139.5 to 120.5 , from 124.3 to 99.0 and from 104.5 to $81.0 \mathrm{~N}$ for screw revolving speed of $60 \mathrm{rpm}$ and pellets ration moisture content of 25.74, 30.62 and $36.59 \%$, respectively. Hence, the same results were obtained with other die hole diameters.

On the other hand, the increase of pellets ration moisture contents from 25.74 to $36.59 \%$ the pellets stiffness decreased by $25.09 \%$ with die hole diameter of $8 \mathrm{~mm}$ and screw revolving speed of $60 \mathrm{rpm}$. However, the same trend was obtained with other die hole diameters.

\section{d) Durability of pellets:}

The most critical factor in the performance of pelleting machine is pellets durability. Regarding to the effect of screw revolving speeds, pellets ration moisture contents and die hole diameters in Fig. 6. It can be observed that, the increase of screw revolving speeds from 60 to $180 \mathrm{rpm}$ increases the durability from 96.62 to 97.60 , from 94.63 to 95.55 and from 92.57 to $93.50 \%$ with die hole diameter of $8 \mathrm{~mm}$ and pellets ration moisture contents of 25.74, 30.62 and 36.59 5, respectively. This trend may be due to the increase in the pressure and compaction occurred during pelleting process this results agree with Kaddor et al (2005). Also, the same trend were obtained with other die hole diameters.

Meanwhile, the increase in both die hole diameter and pellets ration moisture contents decreases the pelleting efficiency which, otherwise 


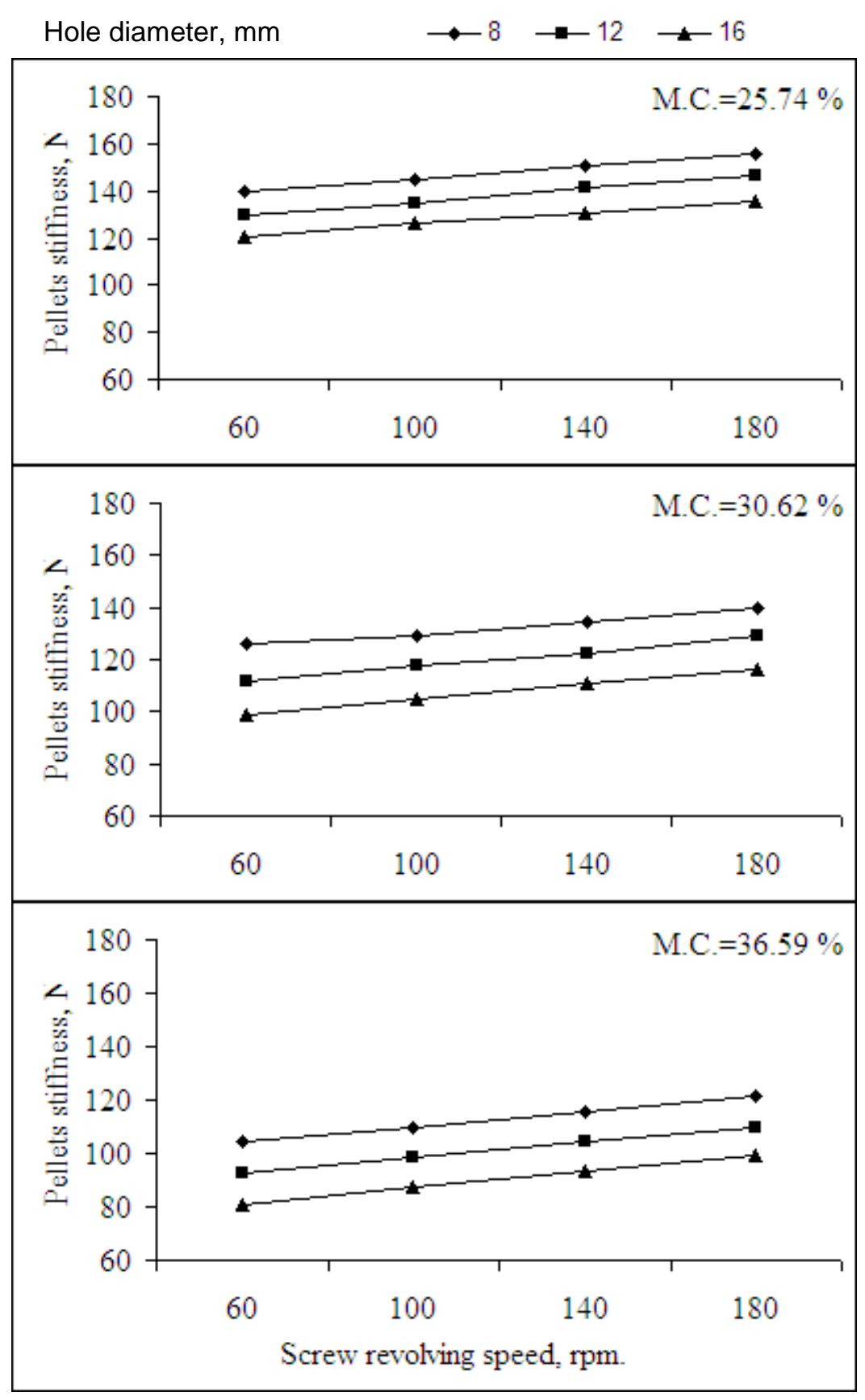

Fig. 5: Effect of screw revolving speed, die hole diameter and ration moisture content on pellets stiffness. 


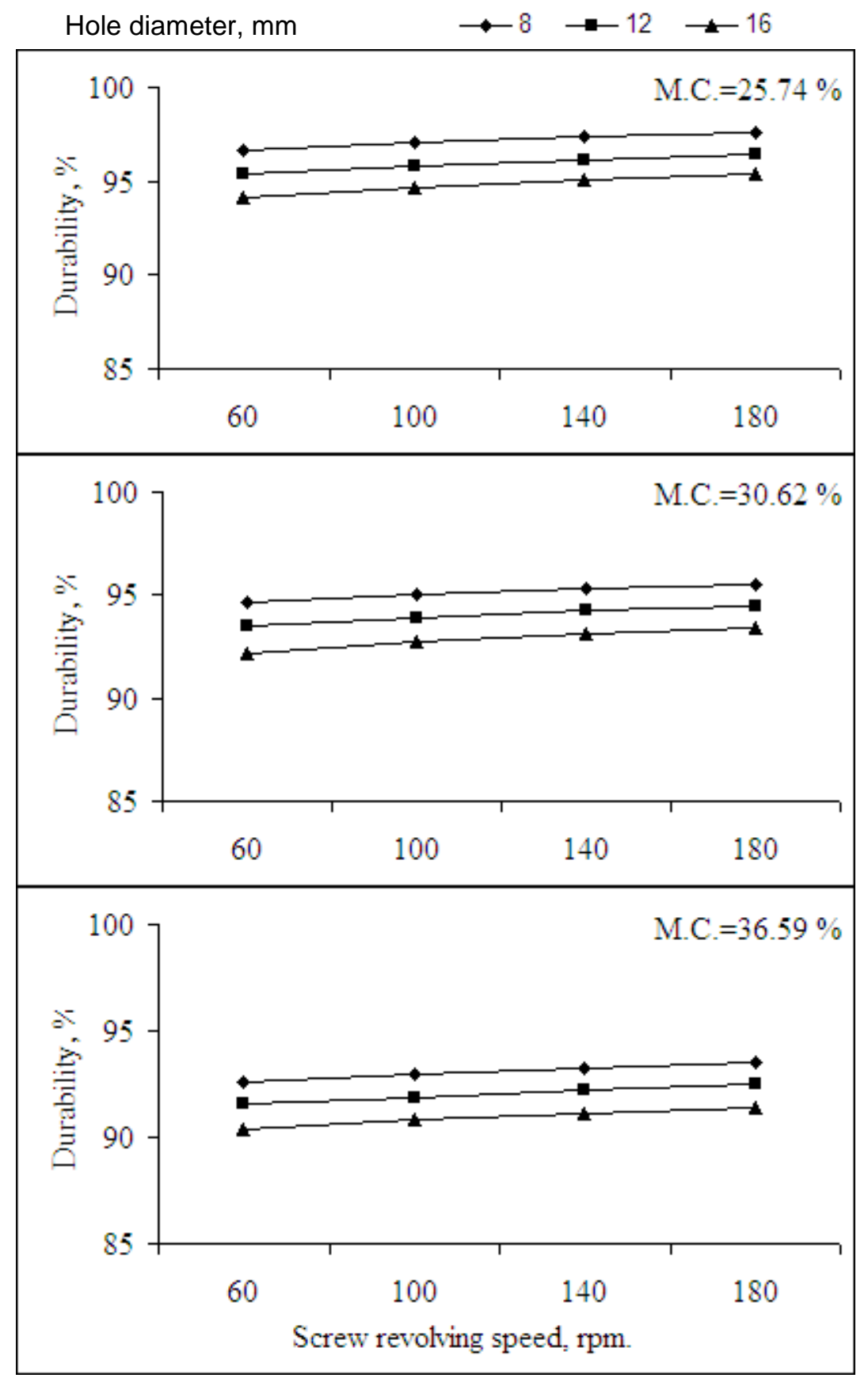

Fig. 6: Effect of screw revolving speed, die hole diameter and ration moisture content on durability of pellets. 
decreases the durability. The increase of pellets ration moisture content from 25.74 to $36.59 \%$ tends to decrease the durability from 96.62 to 92.57, from 95.42 to 91.55 and from 94.15 to $90.35 \%$ with revolving speed of $60 \mathrm{rpm}$ and die hole diameter of 8,12 and $16 \mathrm{~mm}$, respectively. The same results were obtained with other revolving speeds.

\section{e) Pellets bulk density:}

The obtained results in Fig.7 shows the effect of screw revolving speeds, pellets ration moisture contents and die hole diameters on pellets bulk density. It can be evident that, the increase in screw revolving speeds from 60 to $180 \mathrm{rpm}$ tends to reduce the pellets bulk density by $4.82,5.99$ and $7.34 \%$ with die hole diameter of $8 \mathrm{~mm}$ and pellets ration moisture contents of $25.74,30.62$ and $36.59 \%$, respectively. This may be due to the compaction exposed to the ration. The same trend was obtained with other die hole diameters.

On the other hand, the increase in pellets ration moisture content from 25.74 to $36.59 \%$ tends to reduce the bulk density from 2.133 to 1.691 , from 2.175 to 1.742 , from 2.210 to 1.788 and from 2.241 to $1.825 \mathrm{~g} / \mathrm{cm} 3$ with die hole diameter of $8 \mathrm{~mm}$ and screw revolving speeds of 60,100 , 140 and $180 \mathrm{rpm}$, respectively. The same results were obtained with other die hole diameters.

Also, the increase in die hole diameter from 8 to $16 \mathrm{~mm}$ leds to decrease the bulk density by $5.63,6.80$ and $8.57 \%$ with screw revolving speed of $60 \mathrm{rpm}$ and pellets ration moisture contents of 25.74, 30.62 and $36.59 \%$, respectively. The same trend was obtained with other die hole diameters.

\section{f) Pelleting cost:}

Table 3 summarizes the effect of screw revolving speed, die hole diameter and pellets ration moisture contents on machine productivity, energy consumption and pelleting cost. Results observed that, the increase in screw revolving speed from 60 to $180 \mathrm{rpm}$ tends to increase the machine productivity from 0.072 to $0.098 \mathrm{Mg} / \mathrm{h}$. Also, energy consumed reduces from 39.36 to $36.17 \mathrm{~kW} . \mathrm{h} / \mathrm{Mg}$ at the same 


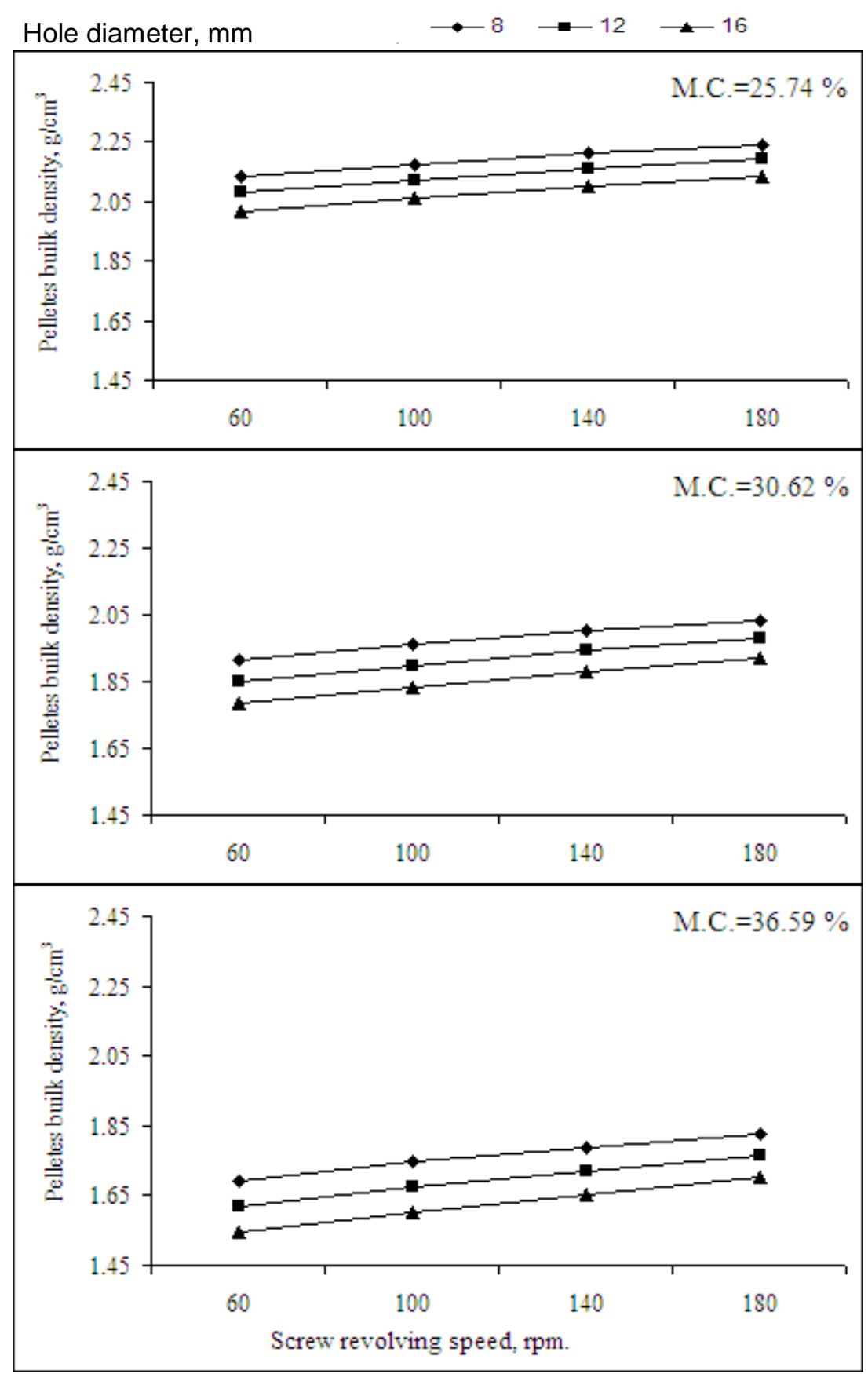

Fig.7: Effect of screw revolving speed, die hole diameter and ration moisture content on pellets bulk density. 
mentioned conditions. However, pelleting cost was reached 105.20 EGP/Mg.

Table 3: Effect of screw revolving speeds, die hole diameter and pellets ration moisture content on machine productivity, energy consumption and pelleting cost.

\begin{tabular}{|c|c|c|c|c|c|}
\hline $\begin{array}{c}\text { Pellets } \\
\text { ration } \\
\text { moisture } \\
\text { content, \% }\end{array}$ & $\begin{array}{c}\text { Die hole } \\
\text { diamete } \\
\text { r, mm }\end{array}$ & $\begin{array}{c}\text { Screw } \\
\text { revolving } \\
\text { speed, } \\
\text { rpm }\end{array}$ & $\begin{array}{c}\text { Machine } \\
\text { productivity } \\
\mathbf{, ~ M g / h}\end{array}$ & $\begin{array}{c}\text { Energy } \\
\text { consumptio } \\
\text { n, kW.h/Mg }\end{array}$ & $\begin{array}{c}\text { Pelleting } \\
\text { cost, } \\
\text { EGP/Mg }\end{array}$ \\
\hline & & 60 & 0.072 & 34.74 & 143.19 \\
25.74 & 16 & 100 & 0.078 & 33.81 & 132.18 \\
& & 140 & 0.086 & 32.99 & 119.88 \\
& & 180 & 0.098 & 31.71 & 105.20 \\
\hline
\end{tabular}

\section{CONCLUSION}

The main results in this study can be summarized as follows:

1- The minimum value of energy consumed reached $23.63 \mathrm{~kW} \cdot \mathrm{h} / \mathrm{Mg}$ at screw revolving speed of $180 \mathrm{rpm}$ die hole diameter of $16 \mathrm{~mm}$ and pellets ration moisture content of $36.59 \%$.

2- Machine productivity of $0.098 \mathrm{Mg} / \mathrm{h}$ seems to be acceptable under the optimum operating conditions.

3- The optimum operating conditions gave the best pellets qualities in terms of stiffness $135.5 \mathrm{~N}$, durability of $95.43 \%$ and pellets bulk density of about $2.136 \mathrm{~g} / \mathrm{cm}^{3}$.

4- Pelleting cost by using the proposed pelleting machine was reached about 105.20 EGP/Mg.

5- The optimum operating conditions of screw pelleting machine was at pellets ration moisture content of $25.74 \%$, die hole diameter of 16 $\mathrm{mm}$ and screw revolving speed of $180 \mathrm{rpm}$.

\section{REFRENCES}

Association of Official Analytical Chemists (1994). Official Methods of analysis $20^{\text {th }}$ ed. Artington, VA.

Abd El-Rahim, Y.M.; A.S.Huzayyin and I.S.Taha (1981). Dimensional analysis and wafering cotton stalks. Trans. of the ASAE, 24 (4): 829-832. 
Bowers, W. (1987). Fundamentals of machine operation Machinery management. Text Book. Deere and Company Moline: 91.

Dobie, J. B. (1959). Engineering appraisal of hay pelleting. Ag. Eng., 40: 76-93.

Dobie, J.B. (1961). Materials handling systems for hay wafers. Ag. Eng., 42 (12) : 692-667.

Fasina, O.O and S. Sokhansanj (1992). Hygroscopic moisture absorption by alfalfa cubes and pellets. Trans. of the ASAE, 35 (5): 1615-1619.

Gupta, P.D. (2001). Mechanization of harvesting pelleting and densitying operations in forages. ASAE, Annual International Meeting.

Ismael, N. K. (2001). Engineering studies on the processing of some agricultural wastes. Ph.D. Thesis, Fac. of Ag., Mans. Univ., Egypt.

Kaddour, U. A; T. R. Owies and H. A. El-Gendy (2005). A study on the effect of using steam-lock in extruder pelleting machine to produce floating fish feed pellets.

Kholief, R. M. (1996). Manufacturing of pellets production machine for livestock. Ph.D Thesis, Fac. of Ag., Kafrelsheikh, Tanta Univ., Egypt.

Khalil, A. A. (2001). Productivity performance of growing lambs fed complete pelleted rations cantaining different levels of dried sugar beet tops. M.Sc. Thesis, Fac. of Ag., Kafrelsheikh, Tanta Univ., Egypt.

Lockwood, F. B. and R. Dunstan (1971). Electrical engineering principles. Meinemann Educational Books, Ltd. London.

Martin, J. H.; W. H. Leonard and D. L .Stamp (1976). Principles of field crop production. $3^{\text {rd }}$ ed., Macmillan Pubi Co., Inc.New York: 877-897.

Agricultural Statistics Ministry of Agriculture. (2009). Ministry of Agriculture and Land Reclamation, Economic Affair Sector.

Ramadan, M. H. (1980). Studies on manufacturing livestock pellets. M.Sc. Thesis, Fac. of Ag., Mansoura Univ., Egypt. 
Susawa, K. (1978). Roughage wavering techniques in Japan. JARQ, 12(1): 17-21, Tropical Agriculture Research Center, Japan.

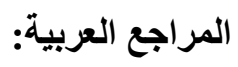

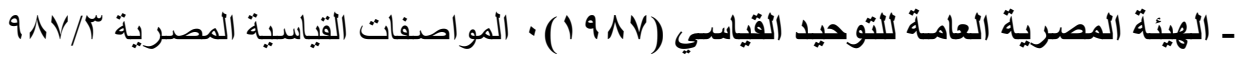
الأعلاف المصنعة ومواد العلف الخام.

الملخص العربي

تصنيع وتقييم نموذج أولى لإنتاج مصبعات العلف

من عرش بنجر السكر التئاجر

د/ رفاعى ابوشعيشع* د/ رزق خليف* د/ حماده الخطيب*

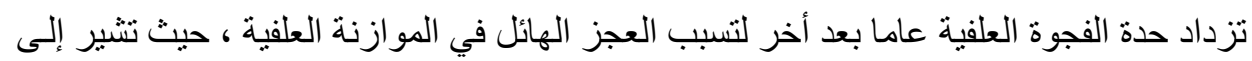

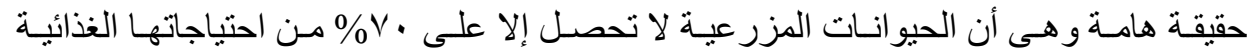

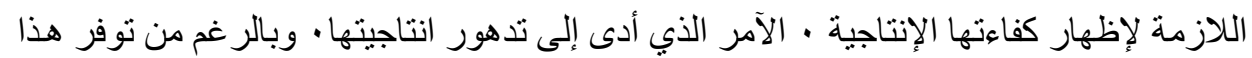

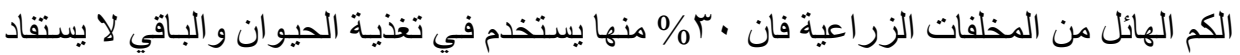

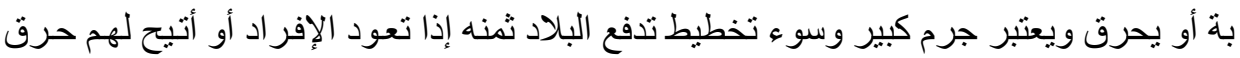

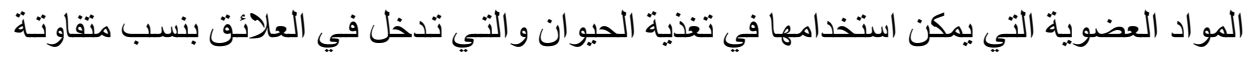

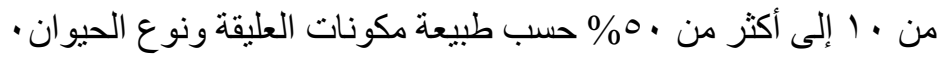

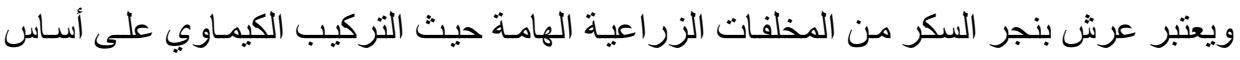

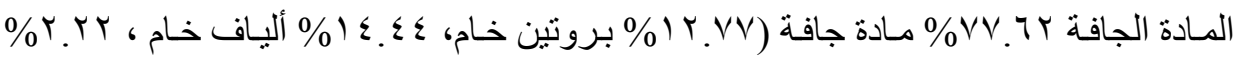

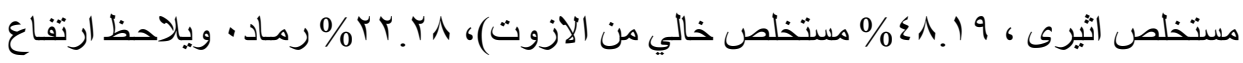

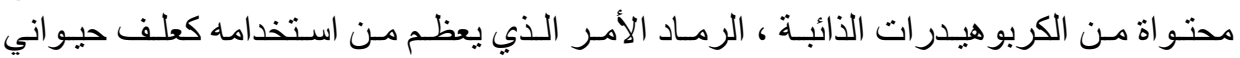

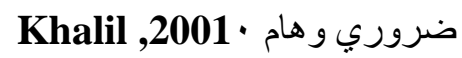

ولقد تم إدخال عرش بنجر السكر بعد تجفيفه وطحنه كمكون رئيسي في العليقة لعمل مصبعات

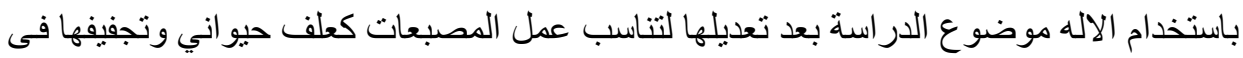

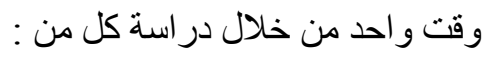

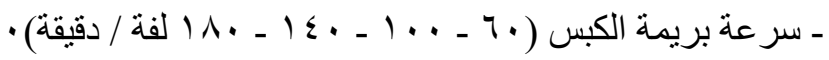

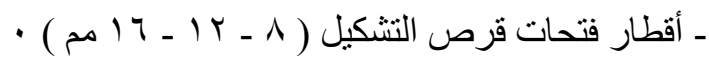

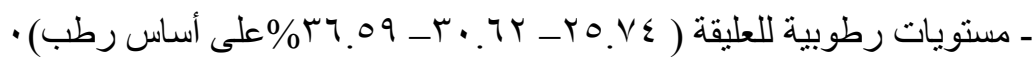

• باحث أول بمعه بحوث الهندة الزراعية ـ مركز البحوث الزراعية ـ الدقى - جيزة . 


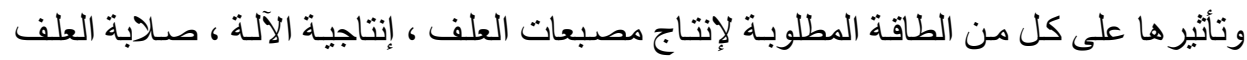

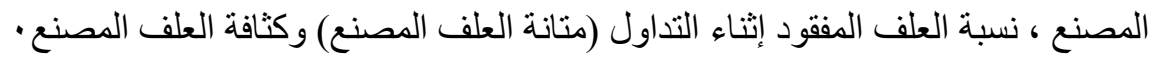

\section{ويمكن تلخيص النتائج المتحصل عليها كما يلي:}

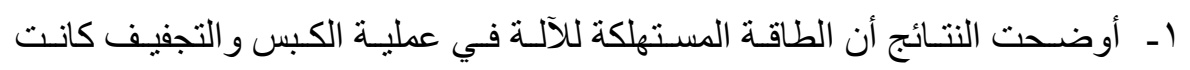

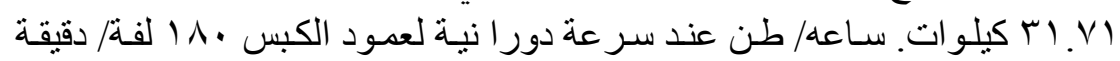

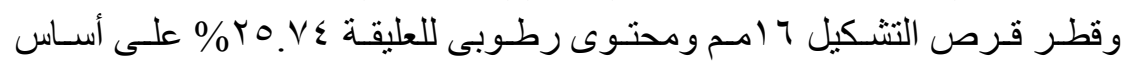
رطب

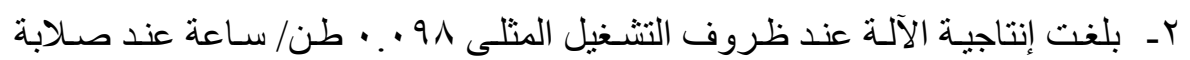

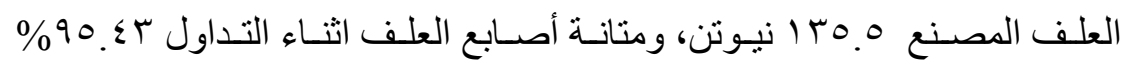

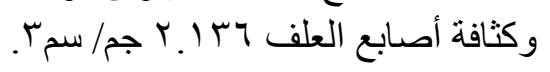

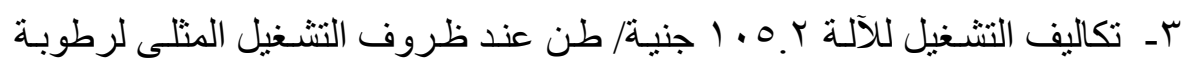

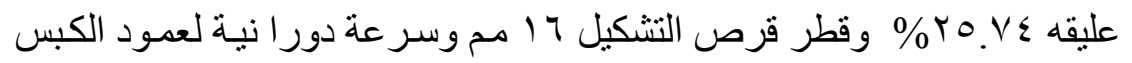
. 11 إنة/ دقيقة. 